\title{
PENINGKATAN HASIL BELAJAR BIOLOGI SISWA MELALUI PENERAPAN MODEL PEMBELAJARAN KOOPERATIF TIPE GROUP INVESTIGATION (GI)
}

\author{
Fitra Halimah Nasution, Iskandar Safri Hasibuan, Jalilah Azizah Lubis \\ Pendidikan Biologi, FKIP Universitas Muhammadiyah Tapanuli Selatan \\ jalilah.azizah@um-tapsel.ac.id
}

\begin{abstract}
The results can be seen from the test results of student learning on Ecosystem materials are characterized by the level of student learning mastery. In cycle I with an average value of 78.10 and in cycle II with an average value of 84.48. From the average value ofcycleIandcycle II there is an average increase of 13.25 . The percentage value in cycle I is $72,41 \%$ with enough qualification. And the percentage in cycle II equal to $86,20 \%$ with very good qualification. From the results of the test cycle I and cycle II has been an increase in percentage of $13.79 \%$. Student learning activities increase by using the GI learning model. The value of activity percentage in cycle $\mathrm{I}$ is $69,4 \%$ with enough qualification. In the second cycle of $80.9 \%$ with very good qualifications. From the results of student learning activities in cycle I and in cycle II has been an increase in the percentage of $11.5 \%$. Based on the results of this study, it can be concluded that there is an increase in student biology learning outcomes through cooperative learning model type Group Investigation (GI) on Ecosystem material in class X MA. Muhammadiyah 06 Kotanopan as prescribed in the action hypothesis in Chapter II so that the hypothesis of this action is acceptable.
\end{abstract}

Keywords: Learning Outcomes, Application of Cooperative Learning Model Type Group Investigation (GI), Ecosystem.

\begin{abstract}
Abstrak
Hasil penelitian dapat dilihat dari tes hasil belajar siswa pada materi Ekosistem yang ditandai dengan tingkat ketuntasan belajar siswa. pada siklus I dengan nilai rata-rata 78,10 dan di siklus II dengan nilai rata-rata 84,48 . Dari nilai rata-rata siklus I dan siklus II terdapat peningkatan rata-rata sebesar 13,25. Dan nilai persentase di siklus I sebesar 72,41\% dengan kualifikasi cukup. Dan persentase di siklus II sebesar 86,20\% dengan kualifikasi sangat baik. Dari hasil tes siklus I dan siklus II telah terjadi peningkatan persentase yaitu 13,79\%. Aktivitas belajar siswa meningkat dengan menggunakan model pembelajaran GI. Nilai persentase aktivitas di siklus I sebesar 69,4\% dengan kualifikasi cukup. Pada siklus II sebesar 80,9\% dengan kualifikasi sangat baik. Dari hasil aktivitas belajar siswa di siklus I dan di siklus II telah terjadi peningkatan persentase $11,5 \%$. Berdasarkan hasil penelitian ini, dapat disimpulkan bahwa ada peningkatan hasil belajar biologi siswa melalui model pembelajaran kooperatif tipe Group Investigation(GI) pada materi Ekosistem di kelas X MA. Muhammadiyah 06 Kotanopan sebagaimana yang telah ditentukan dalam hipotesis tindakan pada Bab II sehingga hipotesis tindakan ini dapat diterima kebenarannya.
\end{abstract}

Kata Kunci: Hasil Belajar, Penerapan Model Pembelajaran Kooperatif Tipe Group Investigation (GI), Ekosistem. 


\section{PENDAHULUAN}

Berdasarkan studi pendahuluan yang telah dilakukan oleh peneliti di MAM 6 Kotanopan melalui wawancara hasil wawancara dengan Ibu Nuraisah Lubis S.Pd yang bertugas menjadi guru biologi di sekolah tersebut. Dimana proses pembelajaran yang berlangsung dengan cara mengajar yang sering diterapkan di kelas adalah menjelaskan materi pelajaran di depan kelas dan siswa mendengarkannya, kemudian menyuruh siswa untuk bertanya bagian yang kurang dipahami dan mendiskusikannya. Kesulitan yang dihadapi siswa adalah memahami bacaan dalam suatu materi pelajaran karena disamping pengetahuan siswa yang terbatas.

Hasil belajar merupakan tujuan akhir dilaksanakannya kegiatan pembelajaran di sekolah. Hasil belajar dapat ditingkatkan melalui usaha sadar yang dilakukan secara sistematis mengarah kepada perubahan yang positif yang kemudian disebut dengan proses belajar. Akhir dari proses belajar adalah perolehan suatu hasil belajar siswa. Hasil belajar siswa di kelas terkumpul dalam himpunan hasil belajar kelas. Semua hasil belajar tersebut merupakan hasil dari suatu interaksi tindak belajar dan tindak mengajar.

Salah satu model pembelajaran yang meningkatkan keaktifan dan hasil belajar siswa dengan menggunakan model pembelajaran kooperatif tipe Group Investigation (GI) dimana siswa belajar kelompok dan dalam suatu kelompok akan diciptakan struktur penghargaan hingga anggota kelompok itu akan saling memberi penguatan sosial sebagai respon terhadap upaya yang berorientasi pada tugas-tugas kelompoknya. Pada hasil temuan Susi $d k k$ (2016), model pembelajaran group investigasi dapat meningkatkan hasil belajar siswa apalagi kepada siswa yang memiliki tingkat motivasi yang tinggi.

Ilmu biologi sangat berpengaruh dan berguna bagi kehidupan sehari-hari.
Mengingat pentingnya kehidupan biologi bagi kehidupan manusia, sudah seharusnya biologi mampu menjadi mata pelajaran yang menarik bagi siswa. Oleh karena itu, tugas guru di kelas tidak hanya menyampaikan informasi demi pencapaian tujuan pembelajaran, tetapi juga menciptakan pengalaman belajar siswa, dan dapat memberikan kesempatan seluasluasnya bagi pengalaman siswa.

Tujuan pembelajaran biologi antara lain adalah mengembangkan cara berfikir ilmiah melalui penelitian dan percobaan, mengembangkan pengetahuan praktis dari metode biologi untuk memecahkan masalah kehidupan individu dan sosisial, merangsang studi lebih lanjut dibidang biologi dan bidang lain yang berhubungan dengan biologi serta membangkitkan pengertian dan rasa sayang pada mahluk hidup.

Tujuan penting dari model pembelajaran kooperatif tipe Group Investigation (GI) ini adalah untuk mengajarkan kepada siswa keterampilan kerja sama dan kolaborasi. Keterampilan ini amat penting untuk dimiliki dalam masyarakat secara budaya makin beragam. Model pembelajaran kooperatif tipe group investigation ini, menjadikan siswa semangat belajar karena ia bersama temantemannya satu ide. Sejalan dengan pendapat Roestiyah (2008) bahwa apabila guru kurang berinteraksi dengan siswa maka proses belajar mengajar akan terasa kurang lancar yang menyebabkan siswa enggan berpartisipasi secara aktif dalam proses pembelajaran dan pemilihan model pembelajaran yang dianggap kurang tepat dapat membuat tidak selarasnya konsep yang akan diajarkan dengan kebutuhan siswa.

Menurut Sudjana (2010), hasil belajar adalah kemampuan yang dimiliki siswa setelah menerima pengalaman belajar. Selanjutnya Warsito (2012) mengemukakan bahwa hasil dari kegiatan belajar ditandai dengan adanya perubahan perilaku ke arah positif yang relatif permanen pada diri orang yang belajar. 
PeTeKa (Jurnal Penelitian Tindakan Kelas dan Pengembangan Pembelajaran)

Vol 1 No 1 Tahun 2017 Hal 28-33

Sehubungan dengan pendapat itu, maka Wahidmurni (2010) menjelaskan bahwa seseorang dapat dikatakan telah berhasil dalam belajar jika ia mampu menunjukkan adanya perubahan dalam dirinya. Perubahan-perubahan tersebut di antaranya dari segi kemampuan berpikirnya, keterampilannya, atau sikapnya terhadap suatu objek.

Pemberian model pembelajaran kooperatif tipe Group Investigation (GI) akan lebih berperan diberikan kepada siswa yang mengalami kesulitan untuk menghubungkan materi pelajaran yang baru tersebut dengan materi pelajaran sebelumnya yang telah dipelajari. Walaupun model pembelajaran kooperatif tipe Group Investigation (GI) memiliki sifat yang besar dalam kegiatan pembelajaran sebagaimana dikemukakan diatas, model pembelajaran koopertif tipe Group Investigation (GI) juga memiliki kelemahan yaitu model pembelajaran kooperatif tipe Group Investigation (GI) tidak cocok diterapkan untuk kelas besar, untuk materi yang sama sekali asing bagi siswa, sangat sulit bagi guru untuk menyusun model pembelajaran kooperatif Group Investigation (GI).

\section{METODE}

Penelitian ini adalah penelitian tindakan kelas atau classroom based action research. Penelitian tindakan kelas adalah solusi atau mencari jalan keluar tentang situasi masalah yang terjadi. Menurut Sumadayo (2013) “ Penelitian tindakan kelas adalah kajian tentang situasi sosial dengan maksud untuk meningkatkan kualitas kegiatan yang ada didalamnya".

Pelaksanaan penelitian ini dilakukan karena ada permasalahan yang dialami dalam pembelajaran. Karena dari hasil tes diagnostik awal yang dilaksanakan terbukti hasil belajar siswa masih rendah.Suatu siklus dikatakan berhasil apabila dicapai hasil yang dihrapkan yaitu minimal diatas KKM, maka penelitian ini tidak perlu dilanjutkan lagi, sebaliknya jika belum tercapai hasil yang diharapkan, maka penelitian masih tetap dilaksanakan ke siklus berikutnya. Prosedur penelitian tindakan kelas ini meliputi: planning (perencanaan), acting (pelaksanaan), observating (pengamatan), dan reflecting (refleksi).

Penelitian dilakukan dengan mengambil subjek penelitian adalah siswa kelas X Madrasah Aliyah Muhammadiyah 6 Kotanopan dengan jumlah siswa 29 orang yang terdiri dari 15 orang laki-laki dan 14 orang perempuan. Dalam penelitian tindakan kelas ini (PTK) akan dilihat indikator kinerja selain siswa dalah guru. Kriteria guru merupakan fasilitator yang sangat berpengaruh terhadap indicator kinerja siswa.

(1) Siswa

Tes: rata-rata nilai hasil belajar siswa.

Observasi: keaktifan siswa dalam proses pembelajaran.

(2) Guru

Dokumentasi: kehadiran siswa.

Observasi: kemampuan guru dalam mengelola pembelajaran.

Teknik pengumpulan data dalam penelitian ini adalah tes dan observasi

(a) Tes

Tes digunakan untuk mendapatkan data tentang hasil belajar biologi siswa dengan cara melakukan tes pada siswa yaitu berupa soal berjumlah 25 .

(b)Observasi aktivitas siswa

Observasi digunakan untuk mengetahui sejauh mana peningkatan aktivitas belajar biologi siswa pada saat proses pembelajaran berlangsung pada materi ekosistem.

Data Dianalisis dengan menggunakan Uji T.

\section{HASIL DAN PEMBAHASAN}

\section{Hasil Belajar Siswa}

Dari hasil yang diperoleh rata-rata hasil tes belajar siswa melalui Pembelajaran Kooperatif Tipe Group Investigation (GI) pada pokok bahasan Ekosistem. Peningkatan hasil belajar siswa 
ditandai dengan ketuntasan siswa dalam proses pembelajaran pada siklus I dan siklus II. Melalui pembelajaran dengan menerapkan Model Pembelajaran Kooperatif Tipe Group Investigation (GI) pada siklus I nilai rata-rata kelas adalah 78,10 dengan jumlah siswa yang tuntas sebanyak 21 orang siswa dan yang belum tuntas belajar 8 siswa. Pada siklus II nilai rata-rata kelas meningkat hingga mencapai 84,48 dengan jumlah siswa yang tuntas belajar sebanyak 25 siswa dan yang belum tuntas 4 orang siswa. Hal ini berarti pembelajaran dengan menerapkan Model Pembelajaran Kooperatif Tipe Group Investigation (GI) dapat meningkatkan hasil belajar siswa pada pokok bahasan Ekosistem.

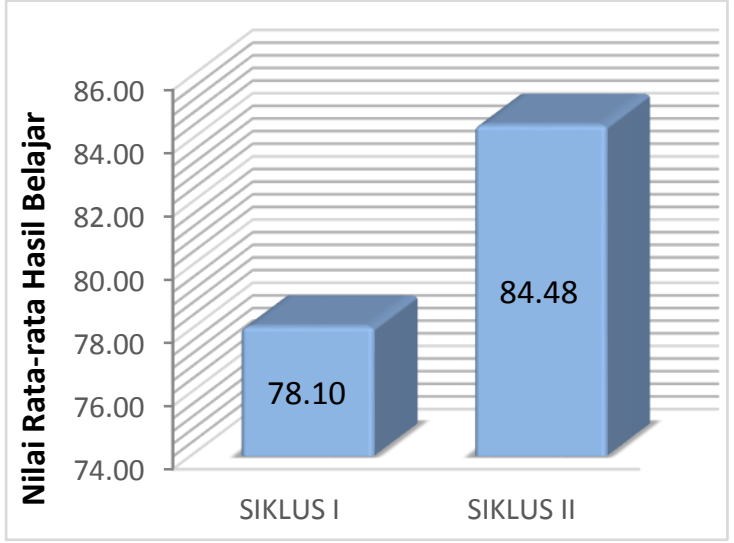

Gambar1: Peningkatan Hasil Belajar Siswa

\section{Hasil Observasi Aktivitas Belajar Siswa}

Berdasarkan hasil penelitian yang telah dilaksanakan, hasil pengamatan dari siklus I dan siklus II dapat dilihat dari peningkatan presentase aktivitas belajar siswa. Dimana pada siklus I hasil observasi aktivitas belajar siswa adalah $69,40 \%$ yang dikategorikan kurang dan pada siklus II hasil observasi aktivitas siswa adalah $80,90 \%$ dikategorikan baik. Dengan demikian dapat dilihat hasil aktivitas belajar siswa meningkat di siklus II dengan jumlah peningkatan $11,5 \%$. Peningkatan Aktivitas Belajar siswa di Siklus I dan Siklus II dapat dilihat pada gambar dibawah ini

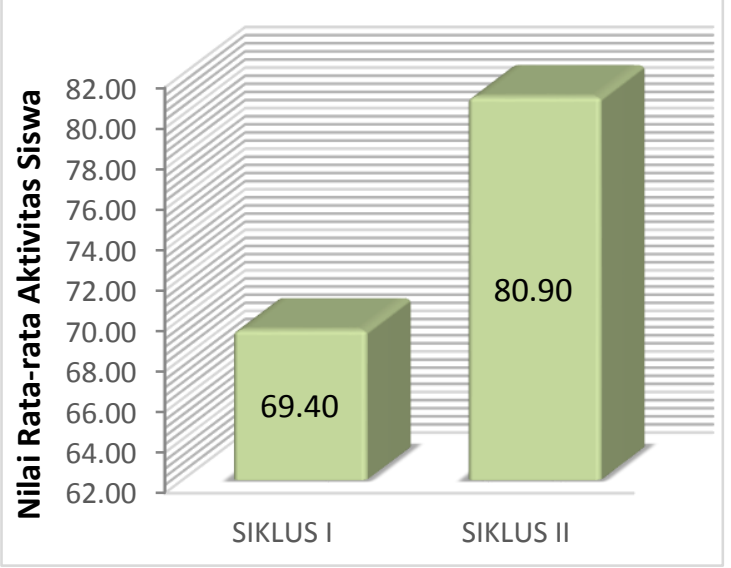

Gambar 2: Peningkatan Aktivitas Belajar Siswa

\section{Hasil Observasi Aktivitas Guru}

Selanjutnya berdasarkan observasi aktivitas guru dalam proses pembelajaran mengalami peningkatan. Pada siklus I masih kategori cukup, masih ada yang kurang dalam mengelola pembelajaran, sehingga aktivitas guru dan siswa tidak berjalan dengan baik. Dimana guru belum dapat mengaitkan materi dengan kehidupan sehari-hari. Guru terlalu banyak memberikan waktu pada siswa untuk bekerja menyelesaikan soal-soal yang diberikan dan guru merasa canggung dan belum terbiasa dengan model pembelajaran GI. Hal ini dapat dilihat dari peningkatan persentase pada siklus I yaitu $62,5 \%$ dengan kategori "cukup" kemudian pada siklus II mengalami peningkatan menjadi $82,5 \%$ berada pada kategori "baik" dengan peningkatan $20 \%$.

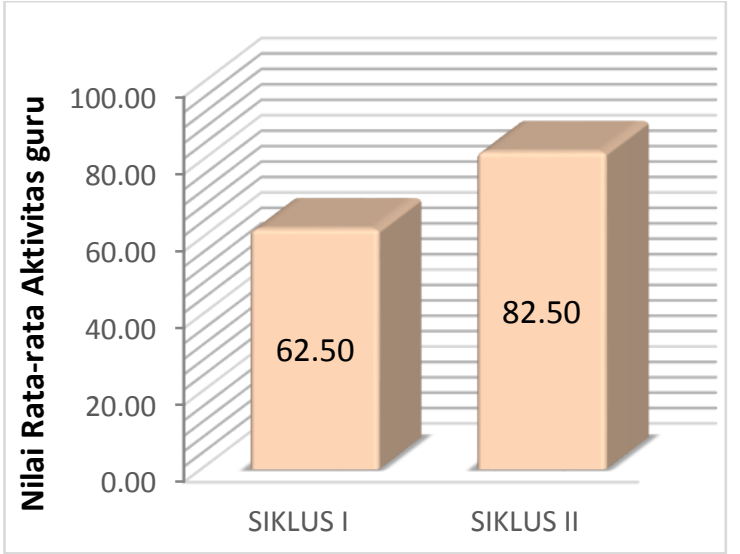

Gambar 3 : Peningkatan Aktivitas Guru 
PeTeKa (Jurnal Penelitian Tindakan Kelas dan Pengembangan Pembelajaran)

Vol 1 No 1 Tahun 2017 Hal 28-33

Adapun hasil dari keseluruhan penelitian dapat dilihat pada table dangan bar di bawah ini:

Tabel 1: Hasil Keseluruhan Penelitian Siklus I dan Siklus II

\begin{tabular}{|c|c|c|c|}
\hline \multirow{2}{*}{ No } & \multirow{2}{*}{ Aspek } & \multicolumn{2}{|c|}{ Siklus } \\
\hline & & I & II \\
\hline 1 & $\begin{array}{l}\text { Hasil Tes } \\
\text { Belajar Siswa }\end{array}$ & $78,10 \%$ & $84,48 \%$ \\
\hline 2 & $\begin{array}{l}\text { Hasil Observasi } \\
\text { Aktivitas Siswa }\end{array}$ & $69,40 \%$ & $80,90 \%$ \\
\hline 3 & $\begin{array}{l}\text { Hasil Observasi } \\
\text { Aktivitas Guru }\end{array}$ & $62,50 \%$ & $82,50 \%$ \\
\hline
\end{tabular}

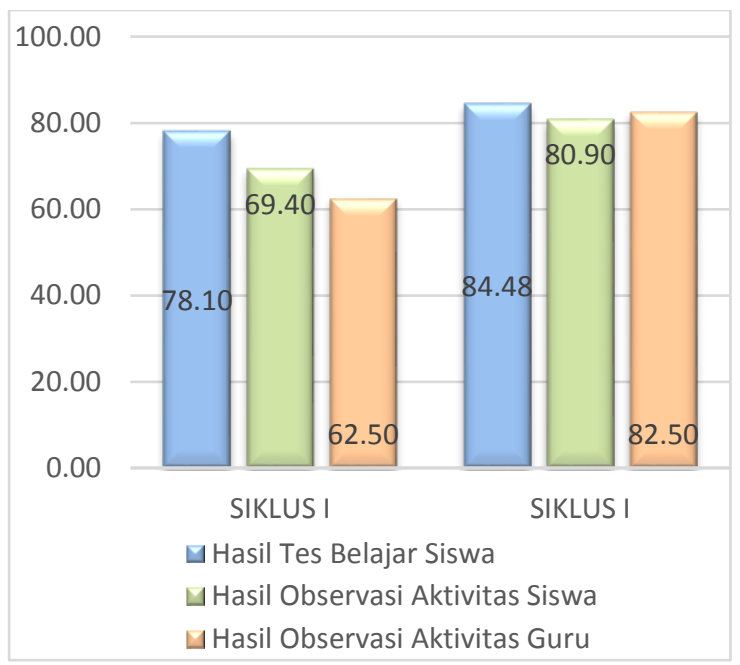

Gambar 4: Hasil Keseluruhan Penelitian Siklus I dan Siklus II

Berdasarkan hasil di atas dapat disimpulkan bahwa guru telah mampu menerapkan Model Pembelajaran Kooperatif Tipe Group Investigation (GI) pada pokok bahasan Ekosistem Di Kelas X MA. Muhammadiyah 6 Kotanopan tahun pelajaran 2016-2017 dengan baik sehingga dapat meningkatkan hasil belajar siswa dalam belajar biologi dan aktivitas belajar siswa dalam proses belajar biologi. sesuai yang disebutkan oleh Wijayanto, dkk (2013) bahwa Metode pembelajaran Group Investigation dapat dijadikan salah satu alternatif untuk meningkatkan aktivitas dan hasil belajar. Teori-teori tersebut telah dibuktikan oleh peneliti dengan hasil penelitian yang sesuai dengan teori yang ada. Guru memberikan penguatan dari hasil presentasi sehingga kemampuan berpikir kritis siswa lebih tajam. Beberapa hal yang harus diperhatikan oleh guru saat menggunakan metode ini yaitu, guru harus dapat memanfaatkan waktu dengan sangat baik dan guru harus dapat mengontrol siswa dengan baik karena saat siswa diskusi akan mengakibatkan kegaduhan di kelas.

\section{SIMPULAN}

Berdasarkan penelitian ini diperoleh kesimpulan sebagai berikut: Meningkatnya hasil belajar siswa pada materi ekosistem dengan tingkat ketuntasan belajar siswa. Pada siklus I dengan nilai rata-rata 78,10 dan di siklus II dengan nilai rata-rata 84,48. Dari nilai rata-rata siklus I dan siklus II terdapat peningkatan rata-rata sebesar 13,25. Dan nilai persentase di siklus I sebesar 72,41\% dengan kualifikasi cukup. Dan persentase di siklus II sebesar 88,20\% dengan kualifikasi sangat baik. Dari hasil tes siklus I dan siklus II telah terjadi peningkatan persentase yaitu $13,79 \%$. Meningkatnya aktivitas belajar siswa dalam proses pembelajaran terlihat pada siklus I dan siklus II. Yang mana pada siklus I dengan nilai rata-rata 60 dan di siklus II nilai rata-rata sebesar 84. Dari hasil aktivitas siklus I dan siklus II terdapat peningkatan rata-rata sebesar 24. Dan nilai persentase interaksi di siklus I sebesar 69,4\% dengan kualifikasi cukup. Dan di siklus II sebesar $80,9 \%$ dengan kualifikasi sangat baik. Dari hasil interaksi belajar siswa di siklus I dan di siklus II telah terjadi peningkatan persentase $11,5 \%$.

\section{DAFTAR PUSTAKA}

Sudjana, Nana. (2010). Metode Pembelajaran. Bandung: Tarsito.

Sumadayo, Samsu. 2013. Penelitian Tindakan Kelas. Yogyakarta: Graha Ilmu.

Susi, Pransiska., Rayandra Asyhar dan Asrial. (2016). Pengaruh 
Fitra Halimah Nasution, dkk. Peningkatan Hasil Belajar...

Penerapan Model pembelajaran Group Investigation dan Motivasi Terhadap Hasil Belajar Siswa kelas VII SMP Dalam Pembelajaran IPA Terpadu Pada Materi Asam, Basa, Dan Garam. Edu-Sains Vol. 5, No 2.

Roestiyah. (2008). Strategi belajar Mengajar. Jakarta: Rineka Cipta.

Wahidmurni. (2010). Cooperative Learning. Jakarta : Grasindo.
Warsito, (2012). Metode Pembelajaran. Jakarta : PT. Rineka Cipta.

Wijayanti.W,. Sudarno Herlambang dan Marhadi Slamet K. (2013). Pengaruh Model Pembelajaran Group Inverstigasi (GI) terhadap kemampuan brpikir kritis siswa kelas X SMA Negeri 1 Mejayan Kabupaten Madiun. Jurnal Online Universitas Negeri Malang. 